\title{
The Geometric Themes in the Mosaics of the Religious Complex of Mértola (Portugal)
}

\section{Mértola Dini Kompleksi (Portekiz) Mozaiklerindeki Geometrik Temalar}

Virgílio António Martins LOPES*

(Received 22 December 2016, accepted after revision 01 July 2017)

\begin{abstract}
The Settlement of Mértola dates from at least the end of the second or early first millennium BC. In the so-called Iron Age, possibly in the third century BC, a walled enclosure with a total length of about 4 kilometres was constructed. This is equivalent to a fortified area of 173 acres. During the period of Roman domination, the city of Mirtylis minted coins and was an important trading port with an important set of structures, such as the forum or the castellum, some private residences and production sites within its walls.

In the late forth century $A D$, when Christianity became the official religion of the Roman Empire, important civil structures were built in Mértola, such as the tower near the river, and religious facilities such as funeral basilicas and a mausoleum. The sacred area developed on the platform of the old forum where, together with two imposing baptisteries, the mosaic fragments were found.

Despite the scarcity of dating elements for the mosaics in Mértola, it would appear that they belong to the sixth century, a historical period in which the members of the community were buried with their epitaphs written in Greek, possibly because of the influence of tastes and fashions from the Byzantine East. During this and the next century, two important basilicas and a mausoleum were built in the suburbs of the city. On the forum, a set of religious buildings would therefore mark the Christian topography of Mértola.
\end{abstract}

Keywords: Mosaic, religious complex, Late Antiquity, Mértola, Portugal.

\section{Öz}

Mértola yerleşimi, en erken İÖ 2. binyılın sonu veya İ̈ 1. binyılın başlarına tarihlenmektedir. Demir Çă̆ı olarak adlandırllan, muhtemelen İ̈̈ 3. yüzyllda, yaklaşık 4 kilometre uzunluğundaki bir sur duvarıla muhafaza edilmiştir. Bu, 173 dönümlük kuvvetlendirilmiş bir alana eşde ğerdir. Roma egemenliği döneminde Mirtylis şehri sikke basmış ve sur duvarları içinde bazı özel konutlar ve üretim alanları ile forum ya da kastellum gibi önemli yapıların bulunduğu önemli bir ticaret limanı olmuştur. İS 4. yüzyılda, Hıristiyanlık Roma İmparatorluğu'nun resmi dini haline geldiğinde, Mértola'da önemli sivil mimarlık faaliyetleri gerçekleştirilmiştir: Nehrin yakınında bir kule ve cenaze törenleri için kullanılan bir bazilika ve mausoleum gibi dini tesisler inşa edilmiştir. Eski forumun platformunda gelişen ve iki adet ihtişamlı baptisteriumu olan kutsal alanda mozaik kalıntıları tespit edilmiştir. Mértola'daki mozaikler için tarihleme unsurlarının kıtlı̆̆ına karşın bunların 6. yüzyıla ait oldukları düşünülmektedir. Çünkü bu tarihlerde, muhtemelen Doğu Bizans'tan gelen beğeni ve moda etkisi ile toplumun üyeleri Grekçe yazılmış epitaphları ile birlikte gömülmüştür. Bu yüzyıl ve sonraki yüzyıl boyunca şehrin banliyölerinde iki önemli mausoleum ve bir bazilika inşa edilmiştir. Forumda bir dizi dini yapı, Mértola'nın Hiristiyan topografyasina işaret etmektedir.

Anahtar Kelimeler: Mozaik, dini kompleks, Geç Antik, Mértola, Portekiz.

\footnotetext{
* Virgílio Antonio Martins LOPES, PhD Archaeology, Bolseiro Pós-Doutoramento da Fundação para a Ciência e a Tecnologia, Centro de Estudos em Arqueologia Artes e Ciências do Património / Campo Arqueológico de Mértola. E-mail: virgilioamlopes@sapo.pt
} 


\section{Historical context}

The small town of Mértola is located in the south of Portugal, in Alentejo, near the mountain range of the Algarve. The history of the city was always strongly conditioned by two factors that shaped its occupation and its importance over time. First, its strategic location: deployed on top of a hill delimited/ bordered by the Guadiana River to the east, and the Oeiras River to the west, it had excellent natural defence conditions. Second, it was the last navigable point of the Guadiana river: upstream of the village, the geological formation of Pulo do Lobo, with a gap of fourteen meters, prevented the progression of vessels to the north, so that Mértola acquired a fundamental importance as the last port of the river. These factors made it an important commercial warehouse in constant contact with a wide internal territory and the Mediterranean Sea. It was from the port of this city that the gold, silver and copper extracted from the bowels of the Iberian Pyrite belt left for Rome - in particular the minerals from the mines of S. Domingos, located on the left bank of the Guadiana, and Vipasca (Aljustrel), also known as "iron hats". Of course, not only people arrived at the port, but also the most diverse products and artefacts from all over the Roman Empire.

In Mértola, excavations of the old forum were carried out in the late $20^{\text {th }}$ century and the first years of the $21^{\text {st }}$ century, uncovering a baptismal set consisting of two monumental baptismal fonts of more than 4 meters length and 1.2 and 5.8 meters depth, and a porticoed corridor based on the dome of the cryptoporticus. A cryptoporticus is a semi-buried structure that sustains an artificial platform and consists of a domed galleria, 32 meters in length and with an average width and height of, respectively, 2 and 7 meters. The floor of the porticoed gallery and deambulatory were covered by beautiful mosaics, from which

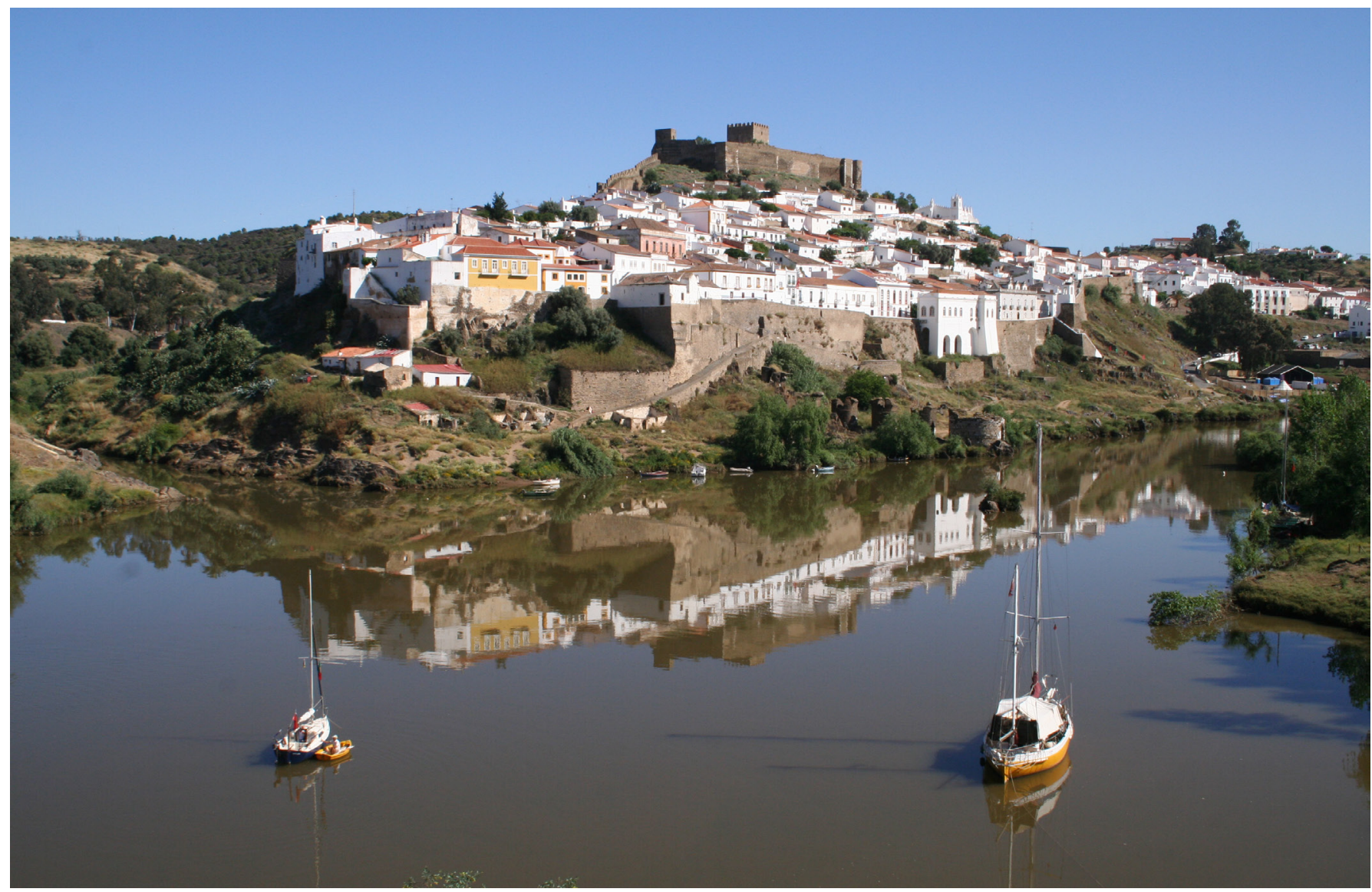


some fragments still remain in situ. These mosaics show several mythological representations, among which are Bellerophon riding Pegasus in order to kill Chimera in the deambulatory of the baptistery, two affronted lions and several hunting scenes with a rider wielding a hawk in the long porticoed hallway (Lopes 2003).

\section{The Mosaics}

A fragment of a mosaic representing a turtle had already been discovered in the fortress area at the end of the $19^{\text {th }}$ century in an excavation led by the archaeologist Estácio da Veiga (Veiga 1983). However, it was only at the beginning of the year 2000 that the team of Campo Arqueológico de Mértola (CAM), brought to light and treated, a long mosaic pavement where a significant set of decorative panels are noteworthy.

Various mythological representations make up this mosaic collection amongst which the following should be highlighted: firstly, situated in the baptistery of the deambulatory, is Bellerophon riding Pegasus to kill Chimera, then in the long portico corridor, two lions facing each other and various hunting scenes with a knight holding a falcon. When looking for parallels for these representations, we should not leave out a reference to a small chapel near Hergla in Tunisia, where a mosaic was discovered, that also portrayed two lions facing each other and a hunting scene with falconry. This collection was dated as coming from the sixth century (Ghalia 2001: 67).

As to the figure of Bellerophon killing Chimera, this scene had, till now, only been found in the Roman city of Conimbriga, but it is relatively frequent in various places in Spain and Tunisia, where its chronology is also linked to the beginning of the sixth century. According to Bairrão Oleiro, this scene of combat between a knight and a monster is, in a certain way, the iconographic forerunner of Saint George killing the dragon (Oleiro 1992: 41).

The plant motifs represented are floral leaf patterns (these predominate) acanthus and roses. The former seems to have a slight indication of landscape, whilst the latter, in a stylized, repeated fashion, appear in the borders of the mosaic panels. The floral motifs allude to Paradise. Temples and basilicas are adorned with flowers; the mosaics of Rome and Ravenna represent the delights of Paradise (Cirlot 1982: 339).

The geometric motifs such as the cornucopia, Solomon's knot, the circles and the pelta are well known in the decorative grammar of the mosaics from the late Roman period and persist in later mosaic representations.

Rather than highlighting the similarities, it is necessary to highlight the differences. The mosaics in Mértola are distinguished by the late Roman mosaic language until now known within Portugal, by the themes and by the fine techniques used, certainly denoting influences not only from North Africa but also the type from Ravenna, influenced by the Byzantine taste.

A closer analysis of the mosaics in the baptismal complex in Myrtilis, allows one to realize that due to the form and quality of the tesserae, the cutting techniques and the way in which they are placed, the programme of work would have been contemporaneous, following the rules of one and the same project. Not to exclude the possibility of having been the same team of mosaicists, certainly coming from the eastern Mediterranean, who carried out this work. If the lack of parallels makes a secure chronology unfeasible, stratigraphic readings allow one to attribute this work to the first half of the $6^{\text {th }}$ century. In this 


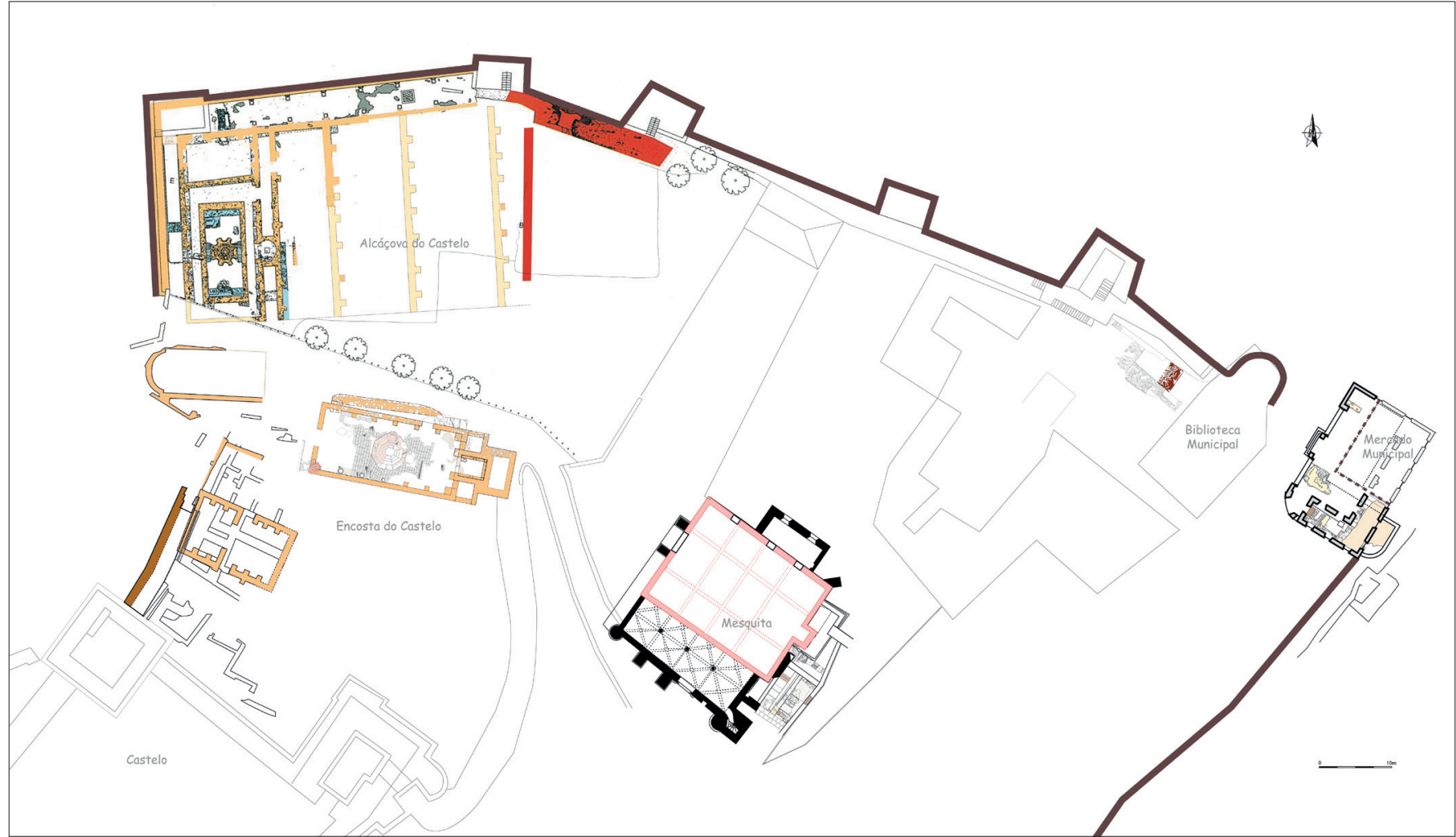

Figure 2

The religious complex of Mértola in Late Antiquity

Figure 3

Panel of lions facing

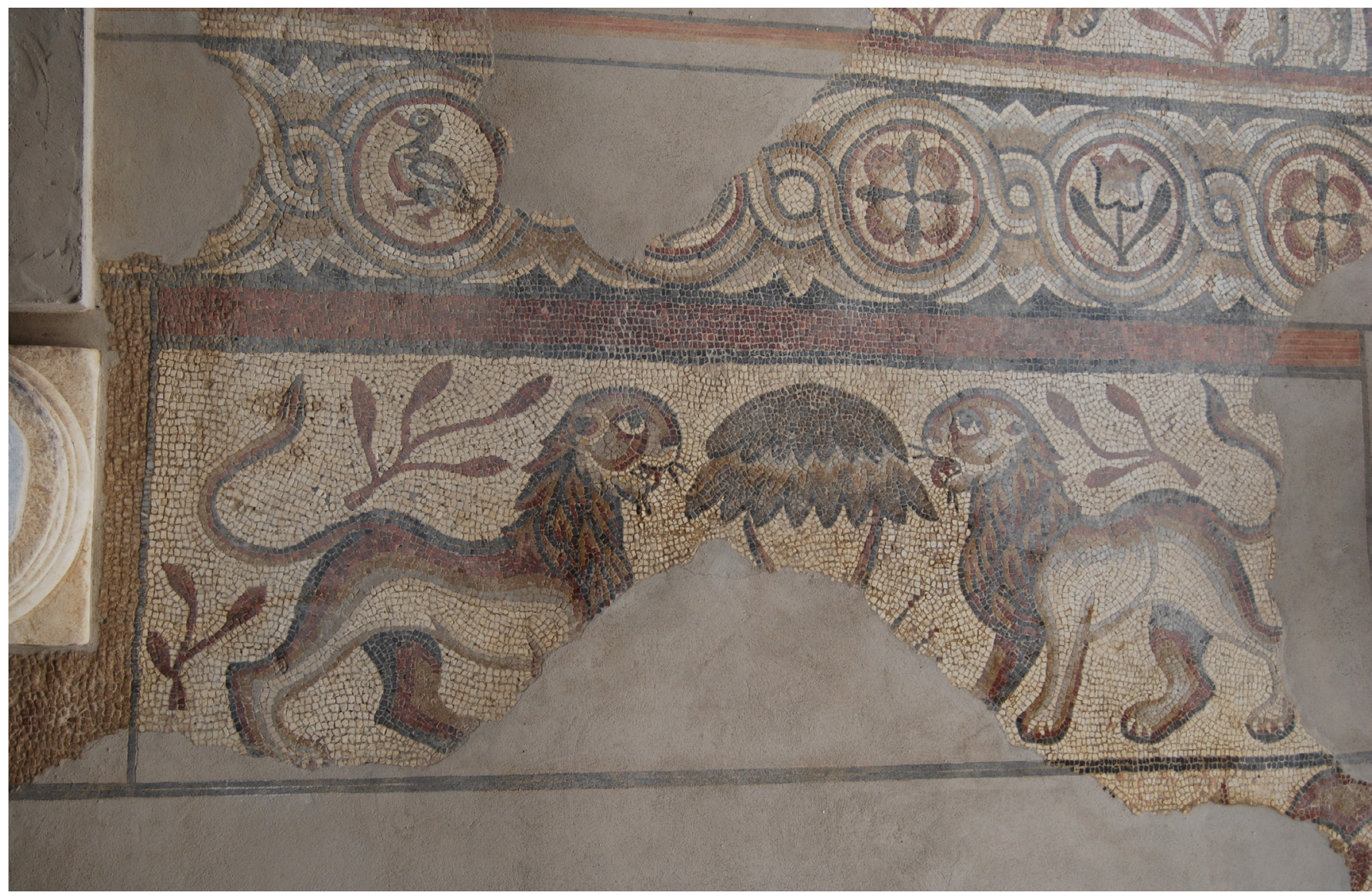




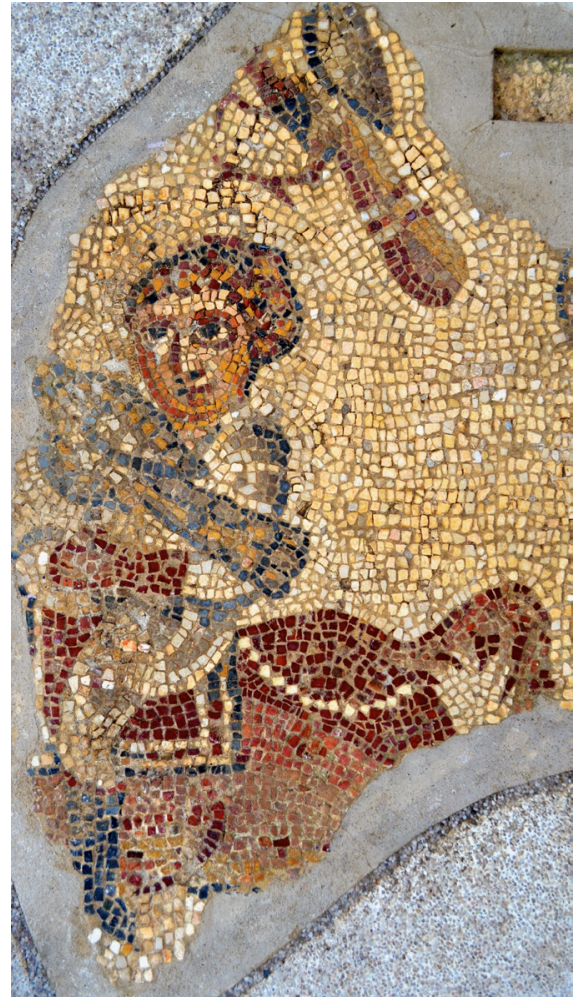

Figure 4

Hunting scene with hawk

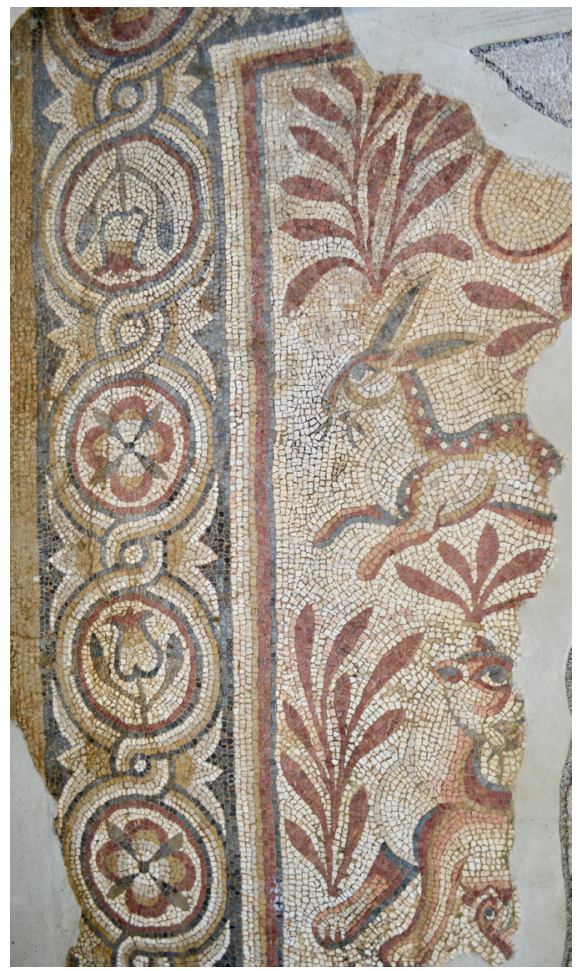

Figure 5

Hunting scene period, the city of Myrtilis and its traders were in contact with all the ports of the Mediterranean, namely with the Middle East, the origin of several individuals buried in the Paleo-Christian Basilica of Rossio do Carmo and in the recently discovered mausoleum.

The Visitors' Circuit around the castle's fortress in Mértola was inaugurated on $25^{\text {th }}$ March 2009. There is a lot projected in this work that will allow organized visits and correct viewing of the mosaics and baptistery as well as access to the cryptoporticus. Furthermore, this intervention has also motivated an in situ conservation programme and restoration of the mosaics on the surface. The project now set up to give value to this area, will allow people to walk around and will contribute to the protection of the existing structures.

\section{The Rossio do Carmo Basilica}

It was possible to detect the existence of glass and limestone tesserae in one of the tombs during the course of the excavations that were carried out in 1990 in the north nave of the Paleo-Christian Basilica in Mertola. In most cases, these were separated from their original setting. Merely a fragment remains attached to the original mortar of the setting. Only a small amount of tesserae were found in situ in the upper part of a tomb, situated in the north entrance to the basilica. The various glass and limestone tesserae, as well as the small fragments found in layers of rubble on the north side of the basilica, leads to the assumption that various tombs of this basilica could have had a mosaic covering (Lopes 2003: 122).

\section{The Mausoleum's Mosaics}

The work to upgrade the commercial area in Mértola that took place between March 2008 and February 2009, uncovered an important set of archaeological remains from various periods in the area outside the city walls.

Due to this work, a set of monumental structures embedded in the rocky land were uncovered. They were situated approximately 500 metres to the north of Paleo-Christian Basilica under the present Marques Duque Cinema and Theatre and belonged to the crypt of a mausoleum from Late Antiquity. Some aspects, like the discovery of an ogee arch decorated with a band of Greek crosses dating from the $6^{\text {th }}$ century, indicate that a richly decorated temple of a considerable size would have been built over it.

It was only possible to document part of the building, which would have extended from East to West, as it had been badly destroyed by later constructions in both sectors.

The rooms, situated to the east and the south of the crypt on the level of the pavements, had three rectangular tombs, dug out of the rock in an east west direction. An intact tomb has survived. It has an opus signinum mortar covering, similar to the burials excavated in the Rossio do Carmo Basilica and in the area of the Marques Duque Cinema and Theatre. We think that we are in the presence of a privileged burial ground due to its size, the treatment given to the covering and the prominence of the place it occupies.

The crypt was finally filled up with materials coming from the funereal area itself (tegula, inbrex, surfaces decorated with polychromatic paintings, small fragments of polychrome mosaics and other construction materials). A considerable 


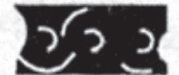

S. M̀. Camí

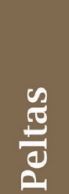

䆜
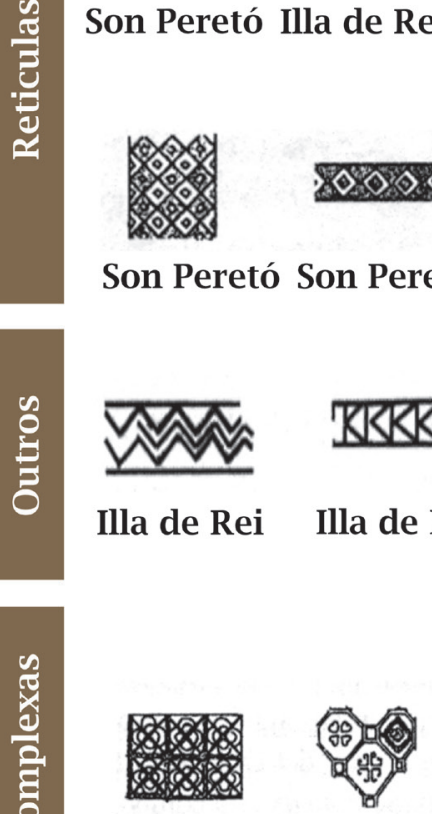

Son Peretó Son Peretó

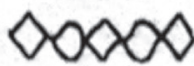

Son Peretó
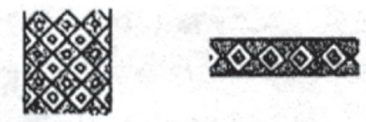

Son Peretó Son Peretó
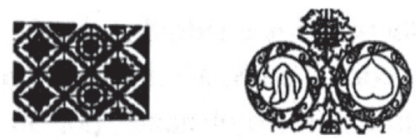

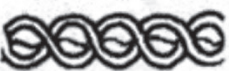

Illa de Rei

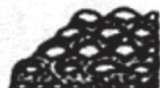

Son Peretó

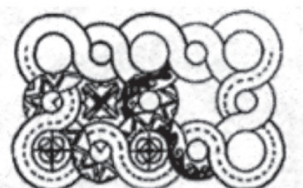

Son Peretó

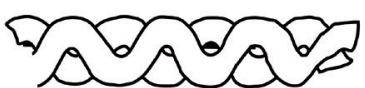

M. Laranjeiras

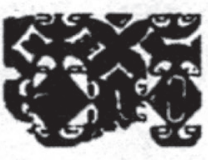

S. M. Camí

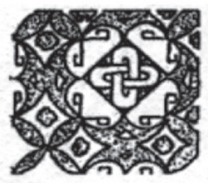

Son Peretó

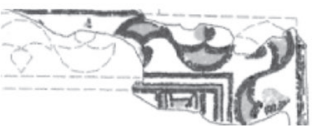

Mértola

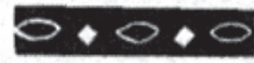

Es F. de Torelló

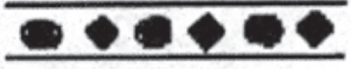

Illa de Rei

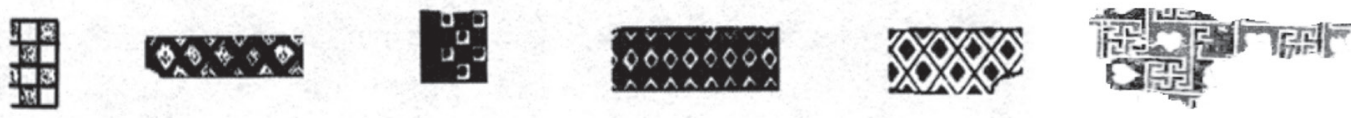
Son Peretó Illa de Rei
S. M. Camí
S. M. Camí
S. M. Camí
Mértola
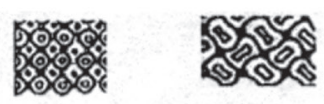

\section{पमT}

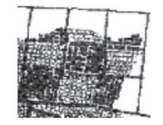

Son Peretó Son Peretó

Illa de Rei

M. Laranjeiras

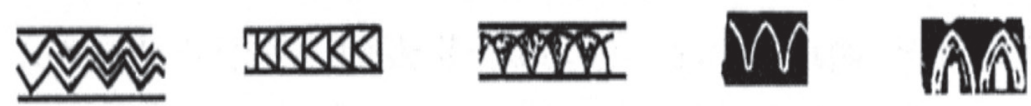

Illa de Rei Illa de Rei Son Peretó
S. M. Camí S. M. Camí

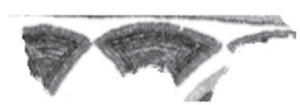

Mértola
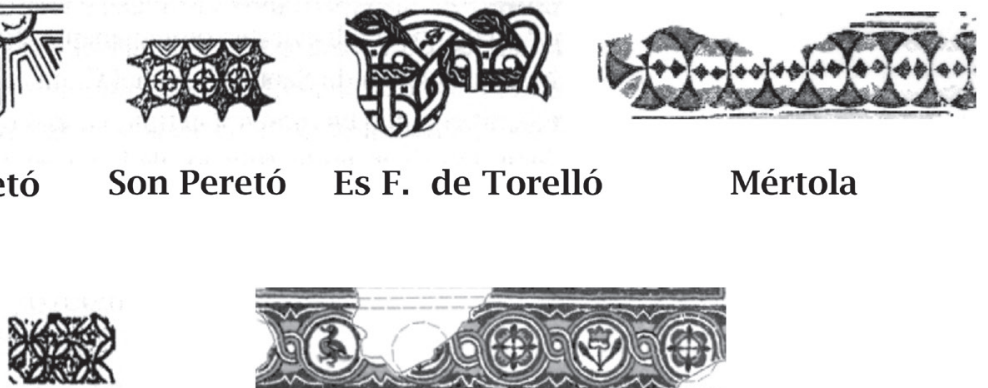

Son Peretó

Es F. de Torelló

Mértola

S. M. Camí Son Peretó S. M. Camí e Son Peretó

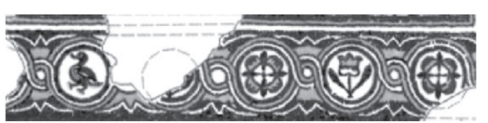

Mértola

Geometric motifs in Hispanic mosaics (adapted from Sánchez Vizcaíno, 2009) 
Figure 7

Geometrric motifs in Hispanic mosaics

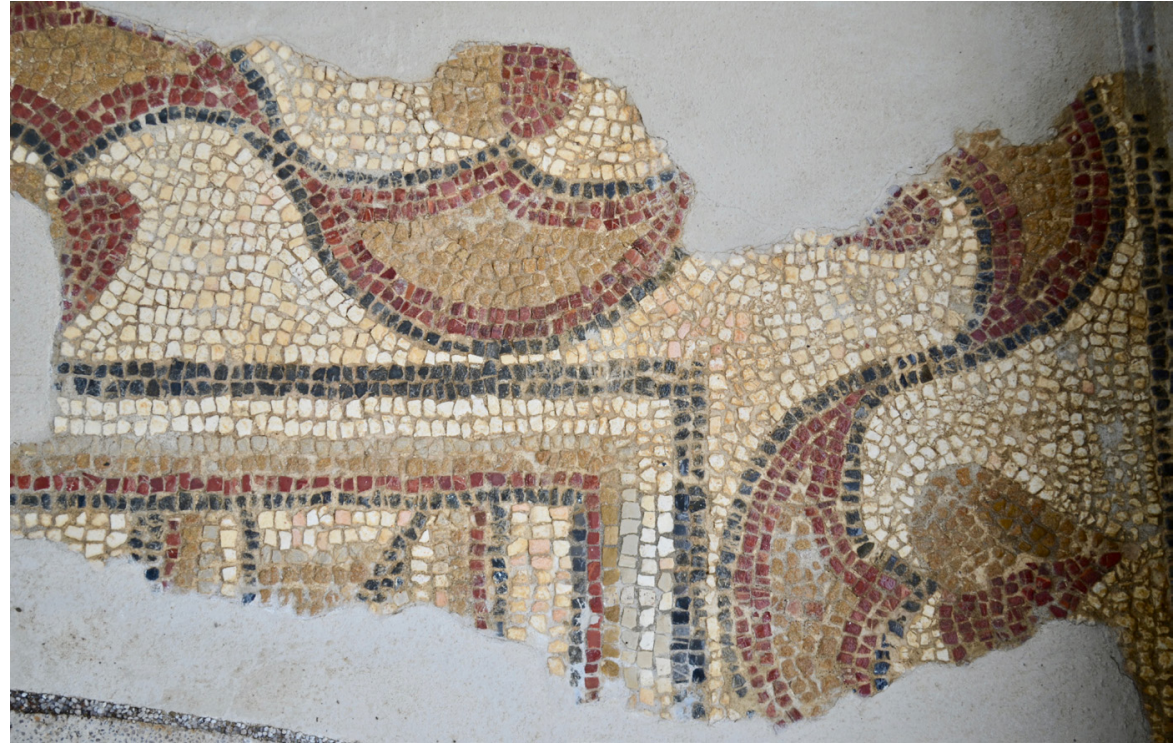

set of tombstones dating from the turn of the $6^{\text {th }}$ century AD is to be highlighted. Three of which are written with Greek letters (Lopes 2014). Information relating to the mosaics is scarce. We can only refer that the tesserae used were of limestone, but we cannot say what the decorative component was.

\section{Conclusion}

This mosaic collection includes several mythological representations, among which we should emphasize a Bellerophon riding Pegasus to slay the Chimera at the baptistery deambulatory, and two affronted lions and various hunting scenes with a knight holding a falcon in the long porticoed gallery, (Lopes 2014). We found similar representations in a small chapel near Hergla, in Tunisia, in which a mosaic depicting two affronted lions and a hunting scene with falcons was discovered - a set dated from the sixth century AD (Ghalia 2001: 153).

As regards the representation of Bellerophon, slaying the Chimera, in the Portuguese territory this scene was only known, so far, at the Roman city of Conimbriga, but it is quite common in various places in Spain and Tunisia, where its chronology is also close to the early sixth century. According to Bairrão Oleiro this combat scene between a knight and a monster is, in a way, an iconographic prefiguration of Saint George slaying the dragon. Following a closer analysis of the mosaics found at the Myrtilis baptismal compound, we find that the work programme was contemporary and belonged to the same consistent project, judging from the form and quality of the tesserae, the cutting technique and the method of application. The same mosaic experts could have done the entire work, certainly from the Eastern Mediterranean. The lack of well-dated parallels makes it impossible to establish a found chronology but the work may be dated from the first half of the sixth century, considering the stratigraphic readings and the stylistic traits. At that time the city of Myrtilis and its merchants were in contact with all ports of the Mediterranean, namely the Near East, whence came several persons buried at the Paleo-Christian Basilica of Rossio do Carmo.

Research enabled us to conclude that the mosaics of the baptismal ensemble of Myrtilis followed the same working programme, as the layout of the motifs and the placement of the tesserae are similar in all of them. Also similar are the size 


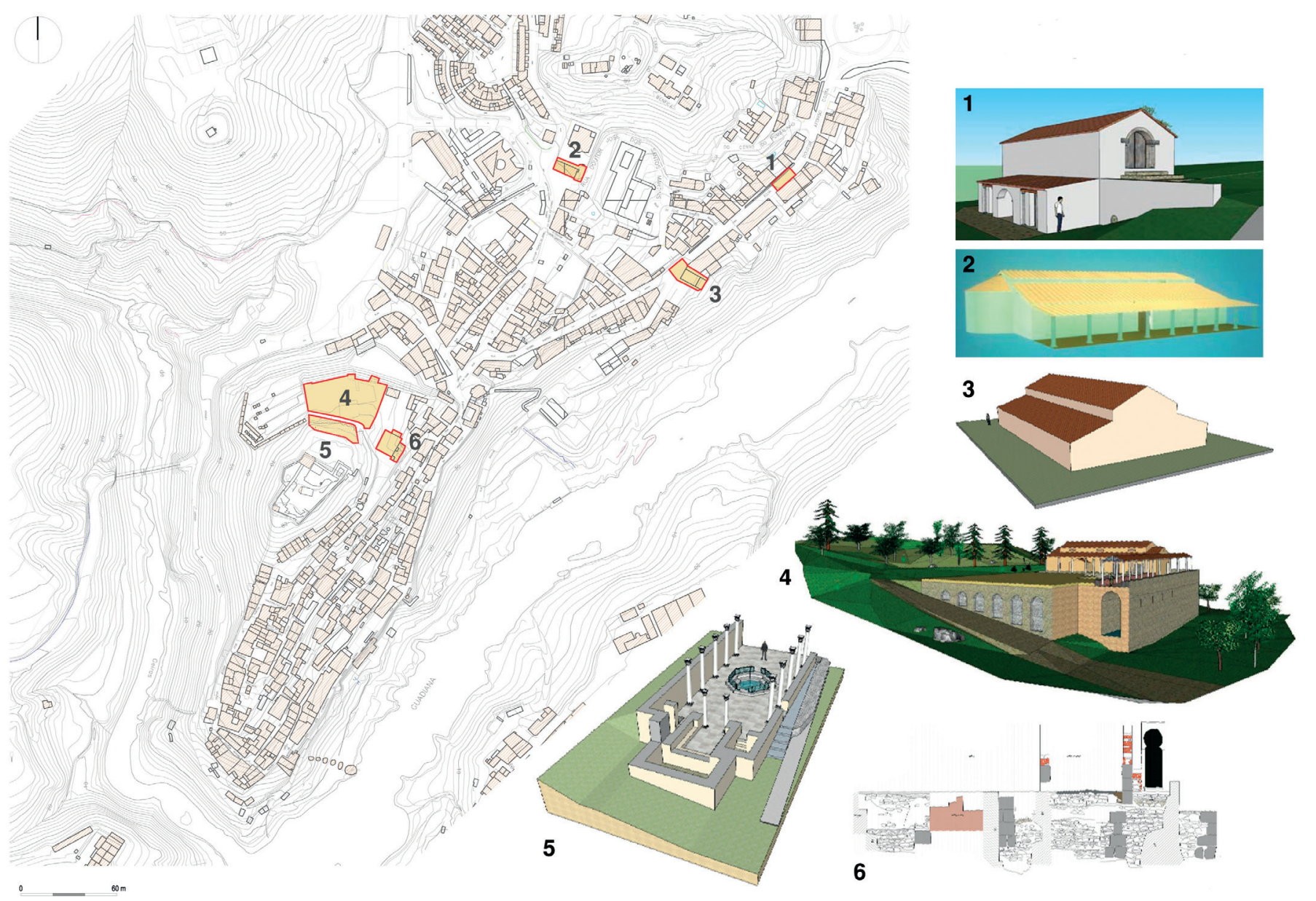

of the tesserae, the chosen colours and the number used for figure composition, as well as the scale of the ensembles. Figures have also been treated similarly and so have the geometric motifs. Plant-like motifs are repeated in the three major groups, namely in the Bellephoron mosaic, in a mosaic found at the Basilica and in the hunting scene. In view of these drivers, we think that the same group of mosaic experts executed all these mosaics. However, the absence of exact welldated parallels renders a safe dating impossible for the time being. We may find several stylistic influences from mosaic ensembles of Northern Africa and even of the byzantine Eastern Mediterranean, certainly related with the importance of the Mértola's port and its merchants in Late Roman trade routes. According to the available data, the mosaics were executed within a time frame ranging from the late fifth to the early sixth century, matching the heyday of Byzantine influence in Southern Iberia and the Balearic Islands (Gouber 1944; 1945; 1946a and 1994b; and, more recently, Vizcaíno Sánchez 2009).

The themes of these traces fits the decorative grammar of Christian and Byzantine mosaics, as in the turtle case, the hunting scene and the Bellephoron myth, as demonstrated by various analyses and comparisons. These mosaics surely belonged to a temple, of which the most significant elements are baptisteries II, key pieces in the ideological promotion of the new cult and places of reference for the believers and I. More importantly, they stood on top of the forum structures, symbols of power in the Roman period, thus symbolically indicating a change of protagonists with regard to local authority. We can look for mosaic parallels in distant Mediterranean locations, but we must remember the examples available at the Balearic Islands, which differ from the Mértola's panels concerning the

Historical topography of Mértola in late Antiquity (1 Mausoleum, 2 Basilica of Rossio do Carmo, 3 Basilica Cineteatro, 4 Religious complex, 5 Baptistery II, 6 Temple before the mosque) 
technical quality of execution. Although the themes of compared cases share the same decorative grammar, the execution quality of Mértola's mosaics deserves to be stressed. As demonstrated above, certain technical details and decorative elements suggest that they were made by the same team of mosaic craftsmen probably from the Eastern Mediterranean.

\section{Bibliography - Kaynaklar}

Åkerström-Hougen 1974

Baratte 1978

Buschhausen 1989

Cirlot 1982

Ghalia 1998

Ghalia 2001

Gouber 1944

Gouber 1945

Gouber $1946 \mathrm{a}$

Gouber 1946b

Lavin 1963

Lopes 2003

Lopes 2014

Oleiro 1992

Piccirillo 1993

Veiga 1983

Vizcaíno Sánchez 2009

Yacoub 1970

Yacoub 1995
G. Åkerström-Hougen, The Calendar And Hunting Mosaics of The Villa of The Fal- Coner In Argos: A Study in Early Byzantine Iconography, Svenska Institutet I Athen, Stockholm.

F. Baratte, F. Catalogue des Mosaïque Romaines et Paléochrétiennes du Musée du Louvre, Paris.

H. Buschhausen, Mosaïques Byzantines de Jurdainie, Musée de la Civilisation Galoromaine de Lyon, Paris.

J.E. Cirlot, Dicionário de símbolos, Barcelona.

T. Ghalia, Hergla et les Mosaïques de Pavement des Basiliques Chrétiennes de Tunisie: Plan, Décore Et Liturgie, Tunis.

T. Ghalia, “Ghalia, La Mosaïque Byzantine En Tunisie”, DossAParis 268, 67-77.

P. Gouber, "Bizance et I'Espagne wisigothique (554-7II)", REByz 2, 5-78.

P. Gouber, P.“L'administration de I'Espagne byzantine”, REByz 3, 127-143.

P. Gouber,“Influences byzantine sur I'Espagne wisigothique”, REByz 4, 111-134.

P. Gouber, P. “L'administration de I'Espagne byzantine“, REByz 4, 70-110.

I. Lavin, The Hunting Mosaics of Antioch and Their Sources: A Study of Compositional Principles In The Development of Early Mediaeval Style, Dumbarton Oaks Papers 17, 179-286.

V. Lopes, Mértola na Antiguidade Tardia, Campo Arqueológico de Mértola, Mértola.

V. Lopes, Virgílio Mértola e o seu território na antiguidade tardia (séculos IV-VIII), Huelva: Universidade de Huelva, Dissertação de Doutoramento, Disponívelem.

J. M. B. Oleiro, "Corpus dos mosaicos romanos de Portugal, I, conventus scallabitanus. Conímbriga: Casa dos Repuxos", Lisboa, IPM-MMC.

M. Piccirillo, M. The Mosaics of Jordan, Amman.

E. Veiga, E. Memórias das Antiguidades de Mértola, Edição Fac-Similada de 1880, Lisboa, Imprensa Nacional/ Câmara Municipal De Mértola.

J. Vizcaíno Sánchez, J. La presencia Bizantina en Hispania (siglos VI-VII): la documentación arqueológica, Murcia, Universidad de Murcia.

M. Yacoub, M. Le Musée Du Bardo - Museée Antique, Tunis.

M. Yacoub, M. Splendeurs Des Mosaïques de Tunisie, Tunis. 
